\title{
ALOYSIUS HUBER AND MAY 15, 1848
}

\author{
NEW INSIGHTS INTO AN OLD MYSTERY
}

One of the memorable days in the French revolution of 1848 occurred on May 15. Several extraordinary events happened on that date. The first was the overrunning of the legislative chamber by an unruly crowd. Next, and most important, a person named Aloysius Huber, after several hours had elapsed, unilaterally declared the National Assembly dissolved. In the resultant confusion, the legislators and the crowd dispersed. Third, shortly afterwards, an attempt took place at the City Hall to set up a new revolutionary government. It failed completely. As the result of these happenings, a number of people thought to be, or actually, implicated in them were imprisoned on charges of sedition.

Damaging consequences followed. Even before that day, a conservative pattern had started to emerge, as revealed by the late-April national election returns and the squelching of working-class unrest at Limoges and Rouen. Paris' day of turmoil sharply escalated the trend. Even though no lives were lost, the dissolution of the legislature and the attempt, no matter how feeble, to launch a new regime, amounted to a violation of the national sovereignty. This greatly offended many in the legislature and among the general public. The anti-working-class current that had started to emerge, but which it might have been possible to absorb, quickly expanded into an ultra-conservative torrent. Very soon after May 15 the authorities began the systematic harassment of the clubs. Only a month later the National Workshops were shut down. This decision, in turn, precipitated the brief but famous June Days class war. Thus May 15 ignited the powder chain that less than six weeks later exploded into civil warfare. ${ }^{1}$

1 Many studies of the Revolution of 1848 exist in which these events are explored. Two good recent ones are Roger Price, The French Second Republic. A Social History (London, 1972), chs 3-4, and Peter H. Amann, Revolution and Mass Democracy. The Paris Club Movement in 1848 (Princeton, 1975), chs 6-9. 
May 15 , then, is remembered as a pivotal point in the 1848 revolution. How should the unexpected events be understood? Clearly, the key incident of the day was Huber's announcement of the dissolution of the Assembly. The preceding crowd intrusion in and of itself reflected only a display of urban feelings concerning an issue of the moment. As for the incident that followed Huber's announcement, that is, the effort to proclaim a new government, this was made possible only by Huber's deed. Who was Huber? What did his act signify? Whom did he represent? Or did he act alone, and, if so, why did he behave in so bizarre a fashion?

Between that day and today, these questions have engendered many answers. The politicians who were the scapegoats for May 15 spoke first. The foremost was François Raspail, the popular club leader and medical innovator. He spent several years in prison for his supposed complicity in trying to overthrow the government on May 15. Raspail stated his absolute conviction that the person who had announced the dissolution of the assembly was a spy and agent provocateur. Huber's purpose had been to strengthen the position of the bourgeois republicans - led by Armand Marrast, the Mayor of Paris - at the expense of the radical republicans, through saddling the latter with the blame for riot and attempted coup d'état. Alexandre Ledru-Rollin, on the other hand, saw Huber as a Bonapartist agent muddying the waters to Louis Napoleon's eventual benefit. Despite the difference in causal attribution, it is significant that each saw him as an agent. As for Huber himself, he claimed at his trial in late 1849 that he had acted solely on his own initiative, declaring the Assembly dissolved in order to forestall a collision between advancing military forces and the milling crowd. ${ }^{2}$ Few believed him. The peculiar occurrences, followed by the subsequent disastrous events, convinced most people that one way or another Huber had been a spy and provocateur.

The historians followed. Georges Renard, contributor to Jean Jaurès's Histoire socialiste, was an early one. After setting forth the obvious reasons why Huber may have been a spy, Renard added that perhaps mental instability explained his act. After Renard, the subject attracted relatively little attention for many years. In the decades after World War II the Huber question, in the agent provocateur form, revived. Proponents of the spy

2 The three views may be found in their original form in Le Moniteur Universel, 1849, pp. 1133-35, 3047; Annales de l'Assemblée Nationale, XXI (1874), p. 282. That LedruRollin's view was incorrect is evident from the fact that Huber publicly supported Ledru-Rollin for the Presidency in December 1848, Aloysius Huber, Au peuple, lettres sur la présidence (Paris, 1848), passim. Ledru-Rollin's notion arose out of his retrospective application of Louis Napoleon's pardon of Huber in 1852 to the latter's behavior in 1848. 
version, directly or by insinuation, included Henri Guillemin and Georges Duveau among French historians, Priscilla Robertson and George W. Fasel among Americans, and J. L. Talmon, the Israeli. ${ }^{3}$ More recently, with the revolution of 1848 subjected to searching analysis, the spy explanation has been superseded. Such contemporary historians as Peter Amann, Frederick A. de Luna and Roger Price now lean to the view that Huber probably did not act as a provocateur. ${ }^{4}$

It is Amann particularly who has focused his attention on Huber and the day that made him famous. In Amann's estimation, May 15 resulted from several converging circumstances. A major factor was that both the demonstration organizers and the authorities acted incompetently. Another ingredient was sheer happenstance caused by crowd movement. Huber's peculiar personality constituted a third. However, his oddity did not include double-dealing as a component. Yet another ingredient - a minor one - consisted of the activity of a few radical acquaintances of Huber who were willing, since the occasion had presented itself, to play with the fire of popular insurrection. As for the authorities, Amann sees their intentions as probably not including any attempt to incite the radicals to misdeeds. In sum, what most prevailed on May 15 was dual ineptitude. ${ }^{5}$

Thus has the issue veered from then until now. Seemingly, whether or not Huber was a spy should have been resolved long ago by consulting the records of the Prefecture of Police. However, as scholars are aware, only fragments of their pre-1871 records have survived. This is because the Communards burned the Prefecture of Police as the Commune of Paris drew to an end. Nonetheless, ways remain by which the lingering haziness concerning the meaning of May 15 and of Huber's part may be diminished. One means lies in examining the existing evidence anew. From this, fresh insights may be extracted. In the case of the archival materials, relatively little more can be garnered, since only bits and pieces of it deal with Huber personally. It is in the printed governmental corpus that much can be

${ }^{3}$ Georges Renard, La République de 1848 [Histoire Socialiste, IX] (Paris, n.d.), p. 52; Henri Guillemin, La Tragédie de quarante-huit (Geneva, 1948), pp. 240-57; Georges Duveau, 1848. The Making of a Revolution (New York, 1967), pp. 115-16; Priscilla Robertson, Revolutions of 1848. A Social History (Princeton, 1952), p. 81; George W. Fasel, "The French Moderate Republicans, 1839-48" (Ph.D. thesis, Stanford, 1965), pp. 344-45; J. L. Talmon, Political Messianism. The Romantic Phase (New York, 1960), p. 452.

4 Amann, Revolution and Mass Democracy, op. cit., pp. 234-35; Price, The French Second Republic, op. cit., pp. 146-47; Frederick A. de Luna, The French Republic under Cavaignac, 1848 (Princeton, 1969), p. 116.

5 Peter Amann, "A Journée in the Making: May 15, 1848", in: Journal of Modern History, XLII (1970), pp. 42-69. 
learned, notably from trial testimony. Also valuable are contemporary newspapers, when compared with each other. Occasionally the comments of well-placed bystanders also are useful.

It is equally essential to examine the principal's personality. Renard and more recently Amann sensed something out of focus in Huber's mental processes. What exactly was it? Here is the heart of the problem. In the documents, it is possible to follow Huber's actions. In one situation after another, his behavior was unusual in repetitive ways. From his conduct, we can deduce his mental condition. With this understood, Huber's critical role on May 15 becomes comprehensible and, more broadly, the various ramifications of the day also gain in clarity. ${ }^{6}$

An important aspect of the Huber question is whether in certain very unusual circumstances that existed in 1837 he acted as an agent provocateur. Clarifying this problem is very important, because it is reasonable to assume that his behavior in this situation sheds light on his actions in the 1848 one. Actually, to understand Huber's proclivity for becoming the center piece in exceptional political developments, it is necessary to backtrack a step further to 1835 . It was in that year that he first came to the attention of the general public.

In 1835 the government easily nipped in the bud an ill-conceived scheme to assassinate King Louis-Philippe known as the Neuilly plot. The three leading participants were the sons of a Widow Chaveau, Gabriel and Charles, and Aloysius Huber. The Chaveau brothers and Huber received prison sentences of several years. At the announcement of the trial verdict Huber drew attention to himself by his outcries, shouting among other things: "We are not assassins, and you have condemned innocent people", and "We are happy to suffer for our wonderful cause; it is impossible to suffer too much".?

It took only two years for Huber to be involved in another plot. In May, 1837 Louis-Philippe, as part of the ceremonies connected with his eldest son's marriage, amnestied many political prisoners. Huber was one. Seven months later, early in December, he was arrested at Boulogne, having lost his documents case containing numerous incriminating messages. These pointed to a scheme by which Laure Grouvelle, a well-known republican spinster, Jacob Steuble, a young Swiss weaponmaker, and Huber had

\footnotetext{
6 Support for the statements in the last two paragraphs will be found in the text and the footnotes that follow.

7 Le Moniteur Universel, 1836, pp. 525-26, 677.
} 
planned to construct an "infernal machine" with which to do away with Louis-Philippe. Huber and Steuble did their work in London, and it was while returning from a trip to the English capital that Huber was captured. Their trial resulted in all three being found guilty. They received harsh sentences. Huber again caused a sensation at the verdict announcement by trying to stab himself and shouting, referring to Laure Grouvelle: "You have sentenced virtue itself". ${ }^{8}$

Eleven years later important new information came to light. It surfaced in connection with the trials of those involved in the May 15 affaire. At Raspail's instigation, Charles-Michel Monnier, a short-term Prefecture of Police employee, testified. He submitted for the record copies of correspondence between Huber and Gabriel Delessert, the Prefect under Louis-Philippe, showing that in 1838, soon after the trial, Huber had sought leniency from Delessert. He based his plea on the claim to have provided Delessert with vital information while the plot was unfolding. The correspondence that Monnier submitted consisted mainly of a letter in which Huber summarized for Delessert the kind of data he had sent, his travels during the conspiracy, and the different handwritings he had used in writing the Prefect. Raspail especially, but also such other figures of the time as Louis Blanc and Daniel Stern, followed later by some historians, perceived in this revelation evidence that Huber had been an agent provocateur in the 1837 plot, and accordingly had acted in the same capacity on May $15,1848 .{ }^{9}$

Amann has pointed out some important unanswered questions that undermine this conclusion. Most of all, if Huber served Delessert as agent provocateur, why did he spend the next ten years in prison? Similarly, why, if he had been acting as a spy, did he find it necessary to write Delessert reminding him of his status? In Amann's assessment, the letter should be regarded as an effort to obtain easement of prison conditions in reward for services supposedly rendered. Huber himself offered this version. At a meeting in London early in 1849 with Marc Caussidière, the pre-May. 15 Prefect of Police, and Louis Blanc he admitted seeking transference to a less rigorous prison in return for co-operation with Delessert, but which he did not give. ${ }^{10}$

${ }^{8}$ Procès de Huber et de ses coaccusés devant la Cour d'Assises de la Seine (Paris, 1838), passim.

${ }_{9}$ Moniteur Universel, 1849, pp. 1031-32,3061-62; Daniel Stern [the Comtesse d'Agoult], Histoire de la Révolution de 1848, 2nd ed. (Paris, 1878), III, pp. 19-21; Dora B. Weiner, Raspail (New York, 1968), p. 211 ; Louis Blanc, Révélations historiques (Leipzig, 1859), II, p. 83.

${ }_{10}$ Peter Amann, "The Huber Enigma: Revolutionary or Police-Spy”, in: International Review of Social History, XII (1967), pp. 190-203, esp. pp. 200-02; Blanc, Révélations historiques, p. 84. 
Certainly the Huber-as-spy-for-Delessert-in-1837 explanation is not correct. This - as Amann notes - suffers from fundamental implausibility, because spies do not have to remind their masters of their service, and receive rewards for it, not punishment. Likewise, however, Amann's version misses the mark, in that it does not sufficiently take into account the way Huber's letter relates to the trial evidence.

It is not a case of Huber falsely claiming to be a spy in order to gain advantage for himself in very difficult circumstances. Rather, he was accurately recapitulating his own actions, particularly as regards to the Prefect, during the period of the plot. His letter contains references to five episodes which, when they are compared with the trial record, turn out to be correctly recalled. In particular, Huber, in referring to approximate times that he had made trips to and from London, stated that he had written letters to the Prefect concerning details of the plotting. When his approximations are compared with the dates of his travels recorded in the trial record, the two mesh. ${ }^{11}$ Moreover, Huber, in writing Delessert, referred in one passage to an incident in which he grabbed Steuble's weapon plans from him, then left them in the custody of a third party in London, returning to Paris. In the trial is testimony on this incident. ${ }^{12}$ Again, he recalled that Laure Grouvelle insisted that he return to London immediately to retrieve the blueprints, and he did so. This episode, too, appears in the trial record. ${ }^{13}$ Most important, Huber mentioned an incriminating letter to a minor official, Leproux, found on his person when arrested at Boulogne. At the trial, one of the most damaging items used by the prosecution was, in fact, the letter to Leproux. Huber explained to Delessert that he had deliberately been caught with the letter on him. ${ }^{14}$

Huber also emphasized in his letter to the Prefect that he had written French ambassador Horace Sebastiani, December 2, 1837, informing him of the conspiracy. No such letter has been found, despite diligent search. Unlike the Prefecture files, the Foreign Office records are intact. The absence of this letter is one of the primary reasons for the thesis that Huber's letter to Delessert should not be taken literally. ${ }^{15}$ But that no trace

11 Thus, he said to Delessert that he returned from London the first time "at the end of August", Le Moniteur Universel, 1849, p. 1032. The actual date was August 30, Procès de Huber, op. cit., p. 44 . He further stated he returned to London a month later; the actual date was September 21 , ibid., p. 45. The third time he returned without his companion, Steuble - true, ibid.; Le Droit (Paris), April 26, 1838.

12 Le Moniteur Universel, 1849, p. 1032; Procès de Huber, p. 45; Le Droit, May 14, 1838.

13 Le Moniteur Universel, 1849, p. 1032; Procès de Huber, p. 50; Le Droit, May 14, 1838.

${ }^{14}$ Le Moniteur Universel, 1849, p. 1032; Procès de Huber, pp. 9-10; Le Droit, April 25, 1838 .

15 Amann, "The Huber Enigma”, loc. cit., pp. 201-02. 
of the letter to Sebastiani has survived is only a minor discrepancy. Possibly, Marshal Sebastiani chose to have a messenger deliver the tip by word of mouth, or ordered the message destroyed upon delivery, or dismissed it as the work of a crank. Testimony at the trial indicated Huber arrived in London on November 30 and departed by December $6 .{ }^{16}$ Thus a letter written December 2 fits within these days.

If the view that in 1837 Huber was not Delessert's agent is incorrect, but so, too, is the version that he pretended to serve the Prefect in order to obtain more lenient treatment, then what does explain his actions? The answer lies in grasping the emotional processes that shaped Huber's behavior.

Certain outward characteristics of the man were very noticeable, causing one person to be struck by one particular trait, a different observer by another. For instance, Emmanuel Arago, his lawyer at the 1838 trial, stressed how "ardent" and "impressionable" his client was. ${ }^{17}$ Similarly, at the Neuilly plot trial, a former employer emphasized his extreme "excitability". ${ }^{18}$ This emotionality often carried with it a marked impulsiveness. Once, about to strike another in anger when informed that this person was very poor, he immediately reversed himself, going far out of his way on his behalf instead. ${ }^{19}$ Sometimes Huber's willingness to inconvenience himself for the sake of others carried him to the lengths of self-endangerment, such as on an occasion in prison when he insisted on being foremost in a risky breakout attempt. ${ }^{20}$ Yet this spirit of self-sacrifice did not always seem genuine. Referring to his courtroom pyrotechnics at the time of the Neuilly trial, the London Times correspondent noted that "it would almost seem that some [...] were anxious to draw upon themselves the heaviest penalties of the law".21

A different kind of observer, Victor Bouton, focused on quite another characteristic. He observed in Huber a considerable vanity and a liking for flattery. ${ }^{22}$ The desire for compliments led him to solicit the approval of

16 Procès de Huber, pp. 9, 46; Le Droit, April 25 and May 14, 1838.

17 Procès de Huber, p. 90.

18 Le Moniteur Universel, 1836, p. 629.

19 Ibid.

20 L. Nouguès, Une Condemnation de mai 1839 (Paris, 1850), p. 181.

21 Times (London), April 11, 1836.

22 Victor Bouton, Profils révolutionnaires (Paris, 1848-49), p. 117. Bouton was a July Monarchy employee, well-informed, with police contacts continuing into the republican era. 
well-known political confrères. Thus, in a letter written just prior to May 15 to the famous romantic insurrectionist, Armand Barbès, he asked, apropos an action he had taken: "And I have done right, haven't I?"'23 Again, years later, in writing a book recalling his prison experiences, he dedicated it in flattering terms to George Sand, who once had given her encouragement to him. ${ }^{24}$ Yet a different personage, Charles Delescluze, the journalist and later Commune of Paris hero, found Huber's unsophistication striking. As he saw him, Huber was "a child in naïveté, knowing nothing of worldly things". ${ }^{25}$

Such were Huber's noteworthy, rather contrasting characteristics. Obviously he had others, but these were the ones that impressed his peers. They were the visible expressions of a specific, distinguishable neurotic character disorder. The histrionics shown at the trial verdicts, the signs of self-absorption, the lability suggested in the near-attack on another at one moment and the deep concern exhibited at the next, the "impressionability" that struck Arago and the naïveté that impressed Delescluze - these are graphically displayed symptoms of the hysterical personality pattern. ${ }^{26}$

Often hysteria is associated with an earlier time and especially with females. ${ }^{27}$ Indeed, it did flourish in the nineteenth century. It was through the study of hysteria by such seminal thinkers as Jean Charcot, Pierre Janet and, especially, Sigmund Freud that a number of the great insights into modern mental illness were elucidated. Had Huber lived in the great Viennese's day, Freud surely would have diagnosed him as a classic study in hysteria. As for its sex distribution, though hysterical tendencies show up far less frequently in males than females, they are by no means limited to the latter. ${ }^{28}$ Fragments of evidence suggest that families living in rural conditions, with the children having only limited exposure to the outer world, may be a little more prone to produce a hysterical personality. ${ }^{29}$

23 Le Moniteur Universel, 1849, p. 3082.

24 Aloysius Huber, Nuit de veille d'un prisonnier d'état (Paris, 1862), Preface.

25 La Révolution Démocratique et Sociale (Paris), March 25, 1849.

26 Paul Chodoff and Henry Lyons, "Hysteria, the Hysterical Personality and 'Hysterical' Conversion", in: The American Journal of Psychiatry, CXIV (1957-58), pp. 734-41, esp. pp. 735-36. This article reviews the subject, and categorizes the common external traits associated with hysteria. Huber had them all.

27 Renato D. Alarcon, "Hysteria and Hysterical Personality", in: Psychiatric Quarterly, XLVII (1973), pp. 258-75, esp. p. 262.

28 P. V. Luisada, R. Peele and E. A. Pittard, "The Hysterical Personality in Men", in: American Journal of Psychiatry, CXXXI (1974-75), pp. 518-21.

29 The Hysterical Personality, ed. by Mardi J. Horowitz (New York, 1977), pp. 165-67; Paul Chodoff, "A Re-Examination of Some Aspects of Conversion Hysteria", in: 
There is just the hint of this situation in Huber's background. His birthplace in 1814 was Ittlenheim, a village northeast of Wasselonne in the Departement of Bas-Rhin, or German-speaking old Alsace. Evidently the family was an agricultural one, for Huber's father was a farmer. ${ }^{30}$

Interpersonal relations of hysterical personalities are characteristically extremely volatile. Immaturity creates the problem. Creatures of emotions, hysterics easily form deep attachments. Other people, in turn, sometimes find their warmth intriguing. Before long the hysteric becomes dependent on the objects of his affection. However, the feeling is subject to swift reversal should disappointment occur. On the other side, those at first drawn to the hysteria-inclined person sooner or later become impatient at what they come to see as self-centeredness, attention-grabbing and capriciousness. The dependent one, unable to cope with the rebuffs, easily lapses into rancor or spite. ${ }^{31}$ It was in exactly this fashion that Huber's relations with others were carried on.

This behavior is best understood in terms of more deeply-rooted characteristics that marked Huber as a hysterical personality. The first of these was a very decided suggestibility. The particular environment in which he found himself had an enormous effect on Huber. ${ }^{32}$ His courtroom dramatics at the time of the trial verdicts is an obvious instance. Hysterics frequently display an inclination for the melodramatic verging on compulsion. Thus one may express or conduct himself in exactly the fashion most appropriate to a specific set of circumstances. What is expressed through the acting and histrionic propensity is a strong susceptibility to identification with other people or surrounding ideas or influences. ${ }^{33}$ In some, the feeling that the environment is about to have a strong impact may induce a kind of auto-suggestibility that anticipates the

Psychiatry, XVII (1954), pp. 75-81, esp. p. 76. Socio-psychic or more especially sociosexual conflict is more likely to exist in such an environment, together with greater tolerance of primitive modes of outward emotional expression.

${ }^{30}$ Mayoral Office, Autun, Saône-et-Loire, France, to author, enclosing certificate of Huber's death in 1865, which gives age as fifty, parents' names, and father's occupation as "cultivateur".

31 Andreas Angyal, Neurosis and Treatment (New York, 1965), p. 147; Klaus W. Berblinger, "Hysterical Crises and the Question of the Hysterical Character", in: Psychosomatics, I (1960), pp. 270-79, esp. p. 276; B. D. Easer and S. R. Lesser, "Hysterical Personality: A Re-Evaluation", in: Psychoanalytic Quarterly, XXXIV (1965), pp. 390-405, esp. p. 399.

32 Cf. Alan Krohn, Hysteria: The Elusive Neurosis (New York, 1978), pp. 219-20; Angyal, Neurosis and Treatment, p. 149; E. Prideaux, "Suggestion and Suggestibility", in: The British Journal of Psychology", X (1919-20), pp. 228-41, esp. pp. 231-33.

33 Anyal, Neurosis and Treatment, p. 143; Otto Fenichel, The Psychoanalytic Theory of Neurosis (New York, 1945), p. 528. 
exterior influence. ${ }^{34}$ In Huber's case Arago, in his reference to his client's "impressionability", voiced his sense of this quality.

The tendency to take on the guise of others - a form of make-believe carried with it an internal equivalent, that is, an inclination in stressful external situations to create his own world of daydreams or semi-fantasy. ${ }^{35}$ This, unlike the histrionics, escaped his contemporaries' notice, but we can perceive traces of it emerging from the public documents. In Huber a final significant trait lay hidden. This was a very strong unconscious sense of guilt, a characteristic not uncommon in his neurosis. ${ }^{36}$ The Times reporter, in his reference to Huber seeming to bring on himself the most severe punishment of the law, caught a glimpse of it. The one who fully grasped it was the author of an extraordinarily perceptive biographical sketch of him in the Grand Dictionnaire universel. He laid emphasis on Huber's "love of playing the martyr". ${ }^{37}$

Authorities lean toward the view that the hysterical neurosis stems from an insufficiency of affection in infancy and early childhood. ${ }^{38}$ More specifically, the psychoanalytical explanation holds that the root cause lies in sexual repression. ${ }^{39}$ The early deficiency in love causes the need for it to continue indefinitely, producing a wishful and preternatural affection for the parent of the opposite sex. ${ }^{40}$ In Huber's case, it is noteworthy that several times he expressed a deep attachment to his mother. ${ }^{41}$ It is the excessive seeking after affection that leads to the histrionics to obtain it, and to the disappointing personal relations. The feeling of inadequacy may create a self-blame that in Huber's case took masochistic form in his "love of martyrdom".

${ }^{34}$ Richard L. Frank, "Conversion and Dissociation", in: New York State Journal of Medicine, LXIX (1973), pp. 1872-77, esp. p. 1875; Fenichel, The Psychoanalytic Theory of Neurosis, p. 528.

35 Thomas L. Hoyer, "Pseudologica Fantastica. A Consideration of the 'Lie' and a Case Presentation", in: Psychiatric Quarterly, XXXIII (1959), pp. 204-20, esp. pp. 203, 208; Ben Karpman, "Lying, A Minor Inquiry into the Ethics of Neurotic and Psychotic Behavior", in: The Journal of Criminal Law and Criminology, XL (1949-50), pp. 135-57, esp. $149,151$.

36 Paul Schilder, "The Concept of Hysteria", in: American Journal of Psychiatry, XCV (1938-39), pp. 1389-413, esp. pp. 1404-05; Bernhard Berliner, "On the Psychodynamics of Masochism", in: Psychoanalytic Quarterly, XVI (1947), pp. 459-71, esp. pp. 460, 461, 465. ${ }^{37}$ Grand Dictionnaire universel (Paris, n.d.), IX, pp. 425-26. The author was exceptionally perceptive, observing not only Huber's martyr complex, but his vanity and his "mania for playing a part".

${ }^{38}$ Krohn, Hysteria, op. cit., pp. 135-37; Angval, Neurosis and Treatment, pp. 139-4l.

${ }^{39}$ Fenichel, The Psychoanalytic Theory of Neurosis, p. 527; David M. Berger, "Hysteria: In Search of the Animus", in: Comprehensive Psychiatry, XII (1971), pp. 271-86, esp. p. 281.

40 Schilder, "The Concept of Hysteria", loc. cit., p. 1404; Krohn, Hysteria, p. 133.

${ }^{41}$ Huber, Nuits de veille, op. cit., pp. 13, 69, 94, 192-93. 
The early traumas leave the hysteric profoundly shaken. Infrequently and in extreme cases this may show up much later in dissociations: the disturbing early memories are repressed, eventually becoming dissociated or disconnected from the core of the personality and acting as a kind of autonomous force. ${ }^{42}$ The rare instances of disconnections in the form of fugues, amnesias and double identities attract public curiosity. In Huber, however, the degree of maladjustment did not extend beyond the hysterical-personality stage. Very infrequently, traces of the more advanced dissociations surfaced. In the 1837 events, a hint of the multiple personality phenomenon appears in his numerous pseudonyms and in his creation of handwritings for very different people, such as a German or a widow. Again, there is a reminder of dissociation in his recollection years later of a solipsistic prison meditation which has a trance-like quality to it. ${ }^{43}$ But on the whole, the hysterical personality did not reach beyond the semiautomization of his suggestibility, and the inclination for histrionics and fantasy.

\section{IV}

The study of Huber in relation to the nature of hysteria opens the door to the resolution of the contradictions that have always plagued efforts to explain his political actions, whether based on the assumption that he was a spy, or on the ground that he was only a radical who marched exclusively to his own tune. The starting point lies in examining Huber's actions in 1837-38, for the understanding of his mental processes in that situation helps greatly in comprehending his frame of mind in the May 15, 1848 period.

It is necessary to realize first that the 1837 "conspiracy" was not in any sense a living, active plot, but entirely a figment of Huber's imagination. This is the conclusion that emerges from a perusal, without preconceptions, of the trial evidence, and of our deeper understanding of the workings of Huber's mind. Thus, a close examination of the trial makes clear that Laure Grouvelle and Jacob Steuble did not serve as Huber's accomplices in a plot against Louis-Philippe, for the reason that both entirely lacked a rational motive for involvement.

Laure Grouvelle had known about Huber while he was in prison for his participation in the Neuilly plot, but she spoke to him for the first time only after his release in May 1837. As Jules Favre, her lawyer, emphasized, it defied all the rules of common sense to believe that she would risk a ${ }^{42}$ Fenichel, The Psychoanalytic Theory of Neurosis, pp. 216-17; Krohn, Hysteria, pp. 123-24.

${ }^{43}$ Huber, Nuits de veille, pp. 121, 136, 142, 313. 
comfortable home life, a sizeable income, and the companionship of relatives and friends, in order to participate in a long-chance conspiracy with a newly released political prisoner and a recently arrived twentyone-year-old foreigner. From the testimony it is obvious that her association with the other two stemmed solely from a highly developed social consciousness. ${ }^{44}$ The possibility that Steuble could have been an anti-government plotter was even more far-fetched. Steuble knew nothing of politics, was interested only in the technicalities of weapons construction, understood not a word of French, and had been in France only three or four months, only to find himself apprehended for complicity in a serious crime! Aghast at so great an injustice, Steuble's lawyer opined that only the sadness of his case exceeded its absurdity. ${ }^{45}$

The question obviously arises as to how the prosecution ever obtained convictions. A procession of incongruities explains it. One factor that severely injured the two innocents was the quantity of "evidence" implicating all three with which Huber had loaded himself at the time of his arrest. The jury evidently did not notice that the incriminating material turned up exclusively on the person of one of the defendants. The lawyers representing Huber's supposed accomplices failed to point this out, apparently in a misguided allegiance to the principle of a defendants' united front. The prosecution, having been handed - thanks to Huber - a veritable treasure trove of treasonous documents, then found it easy after the arrests to induce a few minor informers and petty criminals to testify that the accused had been involved in a dangerous plot. In Laure Grouvelle's case, she had in previous years become publicly known as having sympathy for a pair of poverty-stricken would-be killers of LouisPhilippe, and consequently suffered from guilt by association. As for the bewildered Steuble, his misfortune it was to become associated on a dayto-day basis with the suspicious-acting Huber. Lastly, the jury, influenced to some extent by public feeling, saw the plot as the apparent culmination of a series of attempts on Louis-Philippe's life, and therefore, unmoved by the absurdity of the evidence, rendered a guilty verdict against all three. The announcement of the decision with regard to Laure Grouvelle caused a courtroom sensation. ${ }^{46}$ In prison, conditions before very long drove Steuble to take his own life. Laure Grouvelle refused to accept a pardon for a crime she did not commit, and died of consumption in prison. ${ }^{47}$

44 Procès de Huber, pp. 22, 23, 26, 49-52, 99.

45 Ibid., pp. 12, 13, 23-26, 41, 102.

46 Ibid., pp. 9-10, 22, 56, 65-66, 73, 88, 95, 108.

47 Louis Blanc, Histoire de dix ans (Paris, 1844), V, p. 317; Léon Abensour, Le Féminisme sous le Règne de Louis-Philippe (Paris, 1913), p. 154. 
What had produced this tragedy of misunderstandings was Huber's propensity for suggestion and the volatility of his personal relationships. Once released from prison, he had begun to act out the contagious effects of his surroundings while in custody. Awaiting his prison disposition after the Neuilly trial had given him the opportunity to observe the public behavior of the famous multiple killer Giuseppe Fieschi and to solicit the acquaintance of the much more personally attractive Louis Alibaud. Fieschi had killed many people, but not the King, by means of an "infernal machine" consisting of twenty-four guns fused together in fusillade fashion. ${ }^{48}$ Accordingly, in Huber's effects upon arrest was the sketch of a sixteen gun infernal machine. ${ }^{49}$ At the time Alibaud had tried to kill Louis-Philippe, he had intended next to knife himself. ${ }^{50}$ At the 1838 trial, who made as if to stab himself but Huber? Another of his emulations took the form of a recollection from the Neuilly case. In his letter to Delessert, Huber recalled that one of his disguised handwritings was that of the Widow $\mathrm{Ch} \longrightarrow .{ }^{51}$ An incidental figure at the Neuilly trial was his codefendants' mother, the Widow Chaveau. ${ }^{52}$ Incidentally, in his association with Steuble in London after his prison release, a striking example of his penchant for fantasy turned up at the trial. This was the copy of a "treaty" between the "French Republic" and the weapons craftsman, Steuble. Under Huber's bullying, Steuble had reluctantly agreed to this fictitious pact. ${ }^{53}$

Meantime, Huber's craving for Laure Grouvelle's and Steuble's approbation no longer received nourishment. It was his inability to respond maturely to the breakdown in his close personal relationships that produced the disaster that befell all three. Early in their association, Steuble had felt grateful to Huber for being his first benefactor while he was alone in Paris. By the time they reached London, Steuble had learned that his companion was domineering and unreliable, leading him to try to free himself from his partner's grip.${ }^{54}$ Resentful, Huber, in the course of a trip to Paris by himself, then made a first, unsuccessful attempt to precipitate his

48 Dictionnaire de biographie française (Paris, 1932ff.), XIII, pp. 1302-13 (Giuseppe Fieschi); Procès de Huber, pp. 20, 86. Fieschi's trial and execution took place while the Neuilly case was awaiting trial.

49 Procès de Huber, p. 81.

50 Dictionnaire de biographie française, I, p. 1057 (Louis Alibaud). Alibaud's attempted shooting of Louis-Philippe and his trial and execution occurred a couple of months after the Neuilly trial.

51 Le Moniteur Universel, 1849, p. 1032.

52 Ibid., 1836, pp. 644, 677.

53 Procès de Huber, p. 42.

54 Ibid., pp. 12, 21, 25, 41, 43. 
own detection by means of leaving some very incriminating "evidence" in a very conspicuous place at a friend's domicile. ${ }^{55} \mathrm{Next}$, and much worse for his self-esteem, his relations with Laure Grouvelle deteriorated. For some time, she had admired him as a victim of political persecution. However, increasingly her sympathies focused on the homeless Steuble, arousing his jealousy. When she urged him to return to London to procure Steuble's blueprints, he balked at first, pointing out that this might put the authorities on his trail. ${ }^{56}$ When later he reluctantly agreed, he saw to it that his danger would be self-realizing. While in London, very probably, he wrote Ambassador Sebastiani on December 2. Certainly, en route back, laden with documents implicating his erstwhile friends in his plot fantasy, he arranged for his own capture in Boulogne. ${ }^{57}$

Yet even in the case of a very spiteful person, is it likely he would go to the lengths of ensuring his own imprisonment in order to satisfy his rancor against others? Huber's case is the rare instance that elicits an affirmative answer to this question. First, in his conscious mind, he felt that he deserved only a pro forma punishment. In his letter to the Prefect he asserted that his deeds had saved the King's life ${ }^{58}$ This claim is another illustration of Huber's daydreaming proclivity. In his fantasy world, this imagined service entitled him to a return favor, namely, the imposition of only a minor penalty. Second, and more important, in his unconscious mind, his betrayal of his comrades stirred his sense of guilt, urging him to invite his own imprisonment. Third, when subsequently he was actually incarcerated, this assuaged a related emotional need, the masochistic one: the detention made him a republican victim once more. To repeat the words of his biographer in the Grand Dictionnaire, Huber "loved to play the martyr".

While hysterical personalities suffer from hypersensitivity, they are

${ }^{55}$ At the trial, Huber offered an utterly unconvincing explanation of how it was possible to be so careless as to leave a very suspicious letter at a friend's, Le Droit, May 14, 1838. The reason why he did so becomes clear from the Delessert letter, Le Moniteur Universel, 1849 , p. 1032. He had written the Prefect under the name of Eugene Manay inviting his arrest, so that leaving a dubious letter at a friend's - since he was under police surveillance - was bound to increase the chances of his apprehension.

56 Procès de Huber, pp. 13, 23, 45, 50.

57 Le Moniteur Universel, 1849, p. 1032. Amann, "The Huber Enigma”, p. 201, contending that in his letter to Delessert Huber was only pretending that he was trying to get arrested, points out that he wrote a letter, December 9, to Laure Grouvelle, warning her of his arrest. If he forewarned her, then he could not have been helping Delessert. It is important to observe that he had not mailed this letter. He was arrested December 10 , and searched by the police December 13, at which time, since he had neither mailed nor destroyed it, they found it on his person, Procès de Huber, p. 13.

58 Le Moniteur Universel, 1849, p. 1032. 
notably insensitive to others' reactions to them: ${ }^{59}$ Consequently, Huber completely misjudged Delessert's response to him. As the result, he spent many years in prison. For the Prefect, there were cogent reasons not to grant Huber any favors. At first glance, the one-time currier's unsolicited assistance had made possible a conviction in a treason case that tended to discourage the frequent attacks on Louis-Philippe. However, the verdict proved to be so unpopular that the regime gained nothing by securing it. Second, Huber as a self-actuating, and therefore unguided, spy and informer amounted to a nuisance much more than a weapon, as events had only too plainly made clear. Third, if Delessert ever harbored even the slightest inclination to grant leniency to Huber, the deaths in prison of Laure Grouvelle - driven insane - and Steuble must have obliterated it. These tragedies ensured the government's reputation for heartlessness in this matter. It is no wonder that the Bourgeois Monarchy kept its grip on Huber. Had it lasted a decade beyond 1848 , he probably still would have been in custody.

With the February Revolution, the government, in response to Parisian popular demand, became a republican one. Among the first acts of the new regime came the release of political prisoners. At the time of the revolution Huber, for health reasons, inhabited the prison hospital at Tours. He benefitted from his long detention and, more generally, from the passage of the years. For those who for a decade had harbored their doubts about him, there was no logical explanation of the Huber-Grouvelle-Steuble case that would justify their suspicions. To liberals and radicals, the sensible conclusion to draw was that he happened to be the one of the 1838 victims who had managed to survive. He emerged from Tours hospital, not merely as a free man, but - like Blanqui - a freed prison martyr. Cheered by the local citizenry, he set forth for Paris in a festooned carriage. ${ }^{60}$

In the capital political and social ferment abounded in the spring of 1848. To relieve the high unemployment, the Provisional Cabinet established the famous National Workshops. Nonetheless, the hard-pressed cabinet members had to ride out three tension-ridden demonstrations which fortunately resulted in no violence. Also, a multiplicity of clubs grew up. Through these mostly working-class people were able to voice their

59 Angyal, Neurosis and Treatment, p. 147; Berblinger, "Hysterical Crisis and the Question of the Hysterical Character", loc. cit., p. 277.

60 Gustave Glotz, "Les papiers de Marie", in: La Révolution de 1848, I (1904-05), pp. 151-58, esp. p. 158. 
grievances and express their hopes. In late April the national elections were held. To their disappointment, radicals and socialists did not do well. Several leftists were elected in Paris, but very few elsewhere. Nevertheless, due to the presence of so many unemployed and semi-employed, and the agitation of the radical press and the clubs, the Assembly quickly found itself under pressure to respond to the social unrest. In an atmosphere of easily aroused popular feelings issues of more general European scope also created tension. At this time the Poles were undergoing one of their periodic suppressions at the hands of their neighbors. An outcry arose for a march to the Assembly, where the demonstrators would file their protest against the oppression of the Poles. The Assembly, not wishing to be subjected to the kind of pressure that the Provisional Cabinet had undergone at the time of the demonstrations in March and April, forbade protest marches in its precincts. ${ }^{61}$

Into this complex situation plunged Huber, the free man. Thanks to his new-found popularity, he emerged as a leader in the club movement. $\mathrm{He}$ presided over successive club organizations. One was the Club of Clubs, a co-ordinating body to propagandize the cause of the working-class candidates in the national elections. Since this campaign accomplished very little, the organization dissolved soon after the elections. Then Huber, who felt strongly that the revolution - and within it, the radical wing - suffered severely from division and factionalism, took it upon himself to found a new organization, the Centralizing Committee, the aim of which was to create a greater spirit of unity among the Parisian clubs. The Centralizing Committee achieved very little along this line in the two weeks it was active down to May $15 .{ }^{62}$ Huber, at any rate, in heading up these bodies obtained a prestige but little inferior to that of such famous club leaders as Blanqui, Barbès and Raspail.

In this murky atmosphere, Huber began to be exposed to opposing pressures. One of these came from a focus of extreme leftism that continued despite the election defeat. The spokesman for this viewpoint was Joseph Sobrier. He and his companions occupied a publicly owned building at 16 Rue de Rivoli early in the February Revolution. The Sobrierists used the building as a clearing house for various kinds of radical activity. Sobrier, for instance, published a newspaper, La Commune de Paris, from this address. One of the influential clubs, the Society of the Rights of Man,

61 These events and developments have been studied many times. For a contemporary version, see F.-S.-L. Babaud-Laribière, Histoire de l'Assemblée nationale constituante (Paris, 1850), I, pp. 3-23. Read also Amann, Revolution and Mass Democracy, chs 3-7.

62 Longepied and Laugier, Comité révolutionnaire, Club des clubs et la commission (Paris, 1850), pp. 32-57; Le Moniteur Universel, 1849, p. 3044, 3047, 3078-80. 
met within its portals. ${ }^{63}$ On May 1 this society published a statement that stirred up a great deal of attention, warning the bourgeoisie that it must realize the necessity for giving way to the wants of the working class, on pain of unspecified consequences. ${ }^{64}$ As reflective of the outlook underlying this document, it came out as part of the mop-up following May 15 that at least a few among the Sobrierists, though possibly not Sobrier himself, apparently seriously contemplated trying a coup d'etat; the authorities turned up a group of "Committee of Public Safety" - like decrees in the handwriting of Seigneuret, a Commune de Paris journalist. ${ }^{65}$

The various elements composing the Rue de Rivoli milieu made their impact on the ever-susceptible Huber. The Commune de Paris frequently favored him with references to his doings. He knew Sobrier well. He served as a member of the executive board of the Society of the Rights of Man. The Club of Clubs and its successor, the Centralizing Committee, frequently held their meetings at 16 Rue de Rivoli. ${ }^{66}$ How much this atmosphere influenced him may be gathered from the fact that Huber, despite his professed desire for working- and middle-class reconciliation, lent his name to the Society of the Rights of Man's rather threatening May 1 statement. ${ }^{67}$

Simultaneously, a different magnet, the Mayor of Paris's office, stirred Huber's susceptibilities. It is here that the most important question concerning Huber as a historical figure arises. Did he or did he not serve as an agent for Mayor Marrast? The answer is in the affirmative up to the level of almost complete certainty. Only the lack of formal documentation prevents the making of an absolutely unqualified statement to this effect. A number of interrelated confirmatory circumstances point to this conclusion. The most fundamental relates to Huber's psychological state. In his continuing reaching out for affection, the constant need for the approval of prestigious people made him vulnerable at this time to the blandishments of the Mayor's office. This pattern is discernible in other phases of Huber's life. In 1837 Laure Grouvelle served this need for a time. Meantime, his feelers to

63 Assemblée Nationale, Rapport fait au nom de la commission chargée de l'enquête sur l'insurrection qui a éclaté dans la journée du 23 juin et sur les événements du 15 mai (Paris, 1848), I, p. 19; Longepied and Laugier, Comité révolutionnaire, Club des clubs et la commission, pp. 59, 114.

64 Amann, Revolution and Mass Democracy, pp. 192, 194; Le Moniteur Universel, 1849 , p. 1086.

65 Assemblée Nationale, Rapport, op. cit., II, pp. 268-71; Amann, Revolution and Mass Democracy, pp. 213-14.

66 La Commune de Paris, March 21, 27, 31, April 5, 9, 19, 20, 22, 24, 27, 28, and May 7, 25, 1848; Amann, Revolution and Mass Democracy, pp. 127-31.

${ }^{67}$ Le Moniteur Universel, 1849, p. 1086. 
Delessert represented, in a sense, the search for approval from a different source, a symbol of authority. This showed up yet again when, after the events of 1848-49 had run their course, Huber's public life took a final turn. Serving another long term in prison for what happened on May 15, Huber, in obsequious terms, sought and obtained a pardon from Louis Napoleon, by then the authority figure. Out of prison, he struck up a brief partnership with Pierre Proudhon, who was par excellence a challenger of authority, and yet one who worked toward a modus vivendi with the Napoleon III regime. ${ }^{68}$

When we look at the 1848 situation for confirmation of this authorityassociation, the first sign of it appears in Huber's relations with the Second Republic's top leadership structure. Incidentally, it is worthy of mention that for a militant republican, contact with authority represented less of a contradiction than had been the case under Louis-Philippe, thus making it an easier process. One of the officials with whom Huber had connections was the Minister of Public Works, Alexandre-Thomas Marie. Two letters to him have survived. The second is suggestive. In it, the one-time prisoner remarked that when he was in the prison hospital at Tours, Marie had offered him condolences, and, more striking: "after February 24 [you] showed me a sympathetic interest". The author signed the letter: "Your ever devoted A. Huber."69 Further, he had at least indirect connections with Alexandre Ledru-Rollin, the Minister of the Interior. When the Club of Clubs launched its election campaign, Ledru-Rollin agreed to provide some funds. ${ }^{70}$ Obviously this help carried with it the implicit understanding that the Club of Clubs and the president would pursue a campaign tolerable to the Ministry of the Interior.

These hints of connections with high officials acquire importance only in

68 Ibid., 1852, p. 251; Le Moniteur des Communes, February 23, 1852; Alfred Darimon, A travers la révolution (Paris, 1884), pp. 303-04. All the people named except Laure Grouvelle were from five to twenty-five years-older than Huber. For this pattern in hysterics, see Angyal, Neurosis and Treatment, p. 144, and especially Krohn, Hysteria, pp. 256-57: "the hysterical neurosis may revolve around a pattern of relationships with men, particularly older men in positions of authority. This very common male hysterical pattern shows itself in a tendency to behave obsequiously".

${ }^{69}$ Glotz, "Les papiers de Marie", loc. cit., p. 158.

${ }^{70}$ Longepied and Laugier, Comité révolutionnaire, Club des clubs et de la commission, p. 57; Amann, Revolution and Mass Democracy, pp. 127-28. Exactly which ones among the Club of Clubs members met with Ledru-Rollin is not clear, but the president must have been kept informed, and perhaps attended meetings. Another thread linking Huber to Ledru-Rollin exists. The former was part of a delegation that visited the Justice Ministry, in Ledru-Rollin's name, to obtain a collection of material that included an 1839 pardon request of Huber's and that was not returned. Huber's request for a pardon, February 10, 1852, Archives Nationales, BB ${ }^{21}$, 545-49, Register S, Dossier 3322. 
relation to the larger question of Huber's relations with Marrast. The first stage in exploring this problem lies in observing clues indicating that the Mayor's entourage drew Huber into the Municipality's service. The uncertain conditions during the early months of the Second Republic caused surveillance organizations representing different units of the government to come into being. The Mayor's office sponsored one of these forces. To help defray its costs, Alphonse Lamartine, the Foreign Minister, provided the Mayoralty with 16,000 francs. Interestingly, none other than former political prisoners were among the first to be given employment. ${ }^{71}$ It is probable that this is how Huber became part of the Mayor's service. Athanase Recurt, one of Marrast's adjutants and later a cabinet member, may have recruited him. Recurt, like Huber, was once a secret-society member. Victor Bouton, in his sketches of the 1848 revolutionaries, stated without qualification that Recurt met with Huber in the interest of the Mayor's office. ${ }^{72}$

\section{VI}

This brings us to the 1849 Moniteur trials. These judicial proceedings consisted first of the trial at Bourges in March of the individuals arrested for the May 15 affair, Huber excepted, and its sequel six months later at Versailles, when Huber was tried alone. Unlike the others detained after May 15, Huber managed to hide for a time, then escaped to England, and then returned to be placed in custody near the end of the Bourges trial. Notwithstanding the extra expense, he underwent legal processes later. In unravelling the enigma of May 15, 1848, it is indispensable to realize that these trials were closely interrelated and have a double significance. First, from the standpoint of grasping fully how and why Barbès, Blanqui and Raspail were convicted, it is important to understand that the guilty verdicts were made possible in large part because Huber was tried separately. Second, from the standpoint of scholarly methodology, it is essential to comprehend the peculiar conditions of both trials, but especially of the Bourges one, in order to be able to unravel Huber's relationship to Marrast and the municipality.

Turning first to the Bourges trial briefly, from a methodological standpoint the evidence of Huber's work on behalf of the Mayor, and the signs that the trial conditions were heavily weighted against the defendants, may be found by means of a minute examination of the Moniteur trial evidence

71 Le Moniteur Universel, 1849, p. 963; Auguste Vermorel, Les hommes de 1848 (Paris, 1869), pp. 228-30.

72 Bouton, Profils révolutionnaires, op. cit., p. 117. 
and from a perusal of contemporary newspapers. When aspects of key individuals' testimony is compared with other portions of the Moniteur evidence and, even more, when it is compared with other newspapers' reportage of the same material, there are certain omissions and comparisons that make evident what took place. The crypto-Bonapartist regime took care to profit from several advantages that lay within its grasp. One was the control of the Moniteur. Even more important, the trial was held in an especially constituted court that limited the rules of evidence and the rights of the defendants. Third was the inability of the independent newspapers to do more than report the testimony as rendered verbally. All this enabled the regime to smudge over, but not quite obliterate, the tracks of Huber's march in the Mayor's army.

Meantime, in terms of the defendants' interests, their chances of offering an effective defense were thus greatly inhibited. In the trial, Blanqui vehemently protested inaccessibility of evidence and Raspail unequivocally charged that a coverup was taking place. ${ }^{73}$ It is significant that Huber, who would have been available to testify in the last couple of days of the trial, did not do so. It was at his later trial that he presented his version of his actions. As the result, he did not face the kind of crosschecking that would have occurred, even in a weighted court. No one asked him - as Raspail certainly would have - what he did with his time from day to day or with whom he consulted.

When Huber's case did reach court, the prosecution settled for simply proving his May 15 deed, something that he had already admitted in a newspaper while he was in London. ${ }^{74}$ It did not see fit to explore Huber's relationship to Marrast and his entourage, even though the prosecution owed him no favor. A very good reason underlay this concealment. Huber was not the main target. The proto-Bonapartist regime aimed chiefly at the prominent leftist leaders. By obtaining the convictions of Raspail, Blanqui and Barbès in a trial that did not include Huber, it achieved this goal. Especially before and at the first trial, had it become publicly known that Huber had been serving as informer before May 15, it would have been virtually impossible to convince people that he had not been an agent provocateur on that day. That would have led to the acquittal of the true quarry. Raspail fully and Blanqui partly understood this. It explains why, as we shall see, Raspail made such an all-out effort at the Bourges trial to expose Huber's role, in the process overextending it to include May 15. Even at Huber's trial, had it emerged that he had been a pre-May-15

73 Le Moniteur Universel, 1849, pp. 1193, 1135.

74 La Révolution Démocratique et Sociale, March 14, 1849. 
Marrast informer, this might easily have led to a public demand that the convicted radicals be pardoned or given a re-trial.

To return to the Bourges trial, and Huber's connections with Marrast, Raspail's testimony is of the utmost importance. His charge that the club president was a spy did not gain credence for the reason that Raspail had become obsessed with the notion that there were spies everywhere. In this case, however, his suspicions were well-founded. Through relatives privy to inside information he had access to data that other defendants did not have. As we have seen, it was he who secured Monnier's testimony. ${ }^{75}$ Further, he was able to quote several individuals' words and describe their actions based upon dossiers that evidently had been gathered as part of the investigation that took place immediately after May 15. Subsequently this evidence must have been destroyed, perhaps in the destruction of the Prefecture of Police records at the end of the Commune of Paris, perhaps deliberately long before that. It is especially from passages in Raspail's testimony that the evidence of Huber's service for the Mayoralty may be found.

In the course of testifying, Raspail explained his role in the May 15 demonstration, and as he did so he emphasized that the person in overall charge was Huber, the "intimate friend of Marrast, to whom he wrote every day to give him details on the day's events, a man representing the government itself!" 76 Elaborating, he observed - in reference to how the demonstration was shaping up - that "Huber had informed Marrast that everything would come off peacefully on May 15, for Marrast had every confidence in Huber, who was his man; he wrote him every day, Marrast himself says so (dossier 11 , page 480 )" ${ }^{77}$ One of Huber's letters - the last -

75 Le Moniteur Universel, 1849, pp. 1032, 3061.

76 Ibid., p. 1133.

77 Ibid., p. 1135. It is not clear whether the dossier and other dossiers to which Raspail referred would have been deposited at the Prefecture of Police or at the Archives. At any rate, they do not exist today. In the case of the Archives Nationales, the appropriate place would be as part of C $932 \mathrm{~A}$, Commission d'enquête sur les événements de mai and juin 1848 , documents et correspondance au $2 \mathrm{e}$ volume publié par la Commission, 11 e dossier. Evidently the reports of Marrast's police and the most telling of the post-May- 15 evidence that was in dossiers has disappeared. Another possibility is $\mathrm{C} 908$, but they are not there either. No scholar has ever found them. That they existed is obvious from Raspail's testimony. He referred at various times to dossier 11 , listing numerous specific pages: 31 , $60,63,64,72,75,76,81,321,368,480,488$. He also mentioned dossiers 63 and 76 , pp. 56, 59 and 64 . He could not have manufactured such exact numbers. That the printed record was deliberately left incomplete is shown by how Raspail is quoted in relation to whom he referred. At p. 1135 he referred to Marrast himself as saying that he heard regularly from Huber. Turn to p. 963, and Marrast is not quoted as saying any such thing. Again, Raspail quoted from a dossier something that Huber's Club of Clubs companion, Danduran, said. We look at Danduran's testimony, p. 823, and no such statement is found. It is also 
has survived. Written May 14, the club leader alerted the Mayor to the probability that the demonstration the next day would be more militant than anticipated. Huber's advice was to refrain from calling out the armed National Guard. Then the march would probably come off peacefully, because the demonstrators would not feel provoked. ${ }^{78}$

There is one other strong reason to conclude that Huber was one of those comprising Marrast's secret auxiliary. The clubist's journalistic admirer, Delescluze, fervently believed that he was as loyal a radical as existed anywhere. Even after Monnier's testimony, Delescluze briefly insisted on Huber's radical purity, adding that if by any chance he should prove to be a betrayer, it would be the greatest disappointment of his life. Immediately after he wrote this, Raspail offered his testimony, quoting dossier pages as to Marrast's and Huber's relations. Delescluze must have learned the truth from this, for suddenly Huber's name disappeared from the pages of his journal, never to return. ${ }^{79}$ Evidently Delescluze underwent the bitter letdown that he had regarded as inconceivable.

From all this, we can gather that Huber's function was that of informer. Whereas in 1837 he had been one by self-appointment, this time he did so as a recognized functionary. As club overseer, he was in an ideal position to be aware of unrest and radical plotting. This was exactly the kind of information that moderate republicans like Marrast, Marie and Recurt, if it should become necessary to sidetrack a rapid move toward radicalism, needed most.

In this intrigue-filled environment, Huber moved to capture centerstage, thereby making the May 15 day negatively memorable ever since. To comprehend his deed, it is essential to disconnect it from his pre-May-15 actions. It is at this point that efforts at a plausible explanation have gone astray. The old view, beginning with Raspail and continuing at least through the historian Guillemin, held that Huber, having in all probability been a spy for Marrast, acted on May 15 so as to realize the Mayor's goal of wrecking the radicals. ${ }^{80}$ The newer version, from Amann on, maintains that Huber's May 15 deed by no means accords with an agent provocateur

clear that the independent newspapers, as distinguished from the Moniteur, were not allowed a transcript of the testimony, because they reported Raspail's statements in only truncated form, without the dossier numbers or pages. See, as examples, Gazette des Tribunaux, March 30, 1849, Journal des Débats, March 30, 1849, La Révolution Démocratique et Sociale, March 30, 1849, and Le Constitutionnel, March 31, 1849.

78 Le Moniteur Universel, 1849, pp. 3044, 963.

79 Monnier's testimony appeared March 25, 1849, in light of which Delescluze's rather puzzled defense of Huber appeared in his newspaper. Raspail's testimony appeared March 30, 1849, and from there on no further references to Huber were made.

80 Guillemin, La tragédie de quarante-huit, op. cit., pp. 231-57. 
explanation. The implication in this view is that his activities before that date were only those of a muddle-headed radical. Paradoxically, both arguments are half correct. Amann has demonstrated convincingly that on that day Huber did not act as Marrast's agent provocateur because his deed ruined not just the radicals, but, equally, the moderate republicans, the Mayoral chieftain, and the perpetrator himself. ${ }^{81}$

There are two reasons why there was no connection between the preMay-15 Huber and the Huber of that day. The first has to do with Marrast. As a politician, his defect consisted of being too confident of his own cleverness and sound judgment. On the other hand, nothing in his years as a republican-in-waiting or months as Mayor suggests rashness on the scale required to put Huber up to doing his May 15 deed. ${ }^{82}$ It is not unreasonable to assume that he had sufficient political acumen to realize that if he were to use Huber or any other covert weapon to try to torpedo the radicals, the resultant lapover might sink the moderate republicans as well. Actually, when Huber performed his dissolution, it amounted to a form of defiance, not of fulfillment, of Marrast's wishes.

Second, and more important, it was overwhelmingly Huber's hysterical disposition - just as had been the case in 1837 - that, amidst the daily mounting tension, guided his actions on May 15, rather than anything so rational as prior commitments to Marrast. Furthermore, his responsibility as demonstration supervisor made him even more the slave of his emotions. Evidence of this may be seen in several incidents that occurred in the days before and on May 15. These episodes illustrate the hysteric's inability to control his emotions in times of stress. Three times, in connection with the organization of the demonstration, when confronted with opposition, he flew into a tantrum, once shattering his cane in the process. ${ }^{83}$

\section{VII}

The events of May 15 have been explored many times, most recently and thoroughly by Peter Amann. What has been insufficiently realized is that the message the chief actor's behavior conveyed was much more a

81 Amann, "The Huber Enigma", passim; id., "A Journée in the Making", loc. cit., passim.

${ }^{82}$ For a closeup assessment of Marrast from a republican Constituent Assembly member, see Babaud-Laribière, Histoire de l'Assemblée nationale constituante, op. cit., I, p. 24, wherein the author found him to be perhaps careless in his duties, but incapable of treachery.

${ }^{83}$ Le Moniteur Universel, 1849, pp. 823, 3044, 3046, 3057. 
psychological than a political one. The same characteristics that had dominated Huber's conduct in 1837 did so on this occasion. Again, his connection with a person from whom he needed approval fractured at a critical moment. Once more, he showed himself to be very susceptible to suggestion. Again, in a situation of crisis, he tried to convert his inner world of wishful thinking into an outer world of being. These were primarily interior pressures upon him, but in the course of the Assembly uproar, a well-known exterior sign of hysterical behavior also appeared.

At the time the demonstrators first broke into the Assembly, the first significant incident involving Huber occurred. Despite last-minute warnings of the growing magnitude of the pro-Polish demonstration, Marrast and the other Assembly leaders naturally were hoping that they would be able to see it run its course without the overrunning of the Assembly. In the early part of the siege, Marrast was in the building, and when he spotted Huber in the forefront of the crowd, he angrily ordered him thrown out. ${ }^{84}$ To Huber this meant rejection by one whom he admired. His feeling of humiliation became an important element later in causing him to announce the dissolution. ${ }^{85} \mathrm{His}$ response was similar to his betrayal of his companions after the time in November 1837, when Laure Grouvelle made him return to London.

Huber's ejection did not last long. While others were pouring into the building, he re-entered with them. The day was hot, and with so many people inside, the air was stifling. The intruders pressed incessantly for the club leaders to represent them verbally, and for the deputies to acquiesce in their desires. The constant noise added to the strain. The prominent club men - Raspail, Blanqui, Barbès, even Louis Blanc, a deputy - tried to act as spokesmen for the popular feelings, but with little success. In the case of Raspail and Blanc, at the conclusion of their efforts, the exertions and surrounding pressures brought on fainting spells. ${ }^{86}$

Before this kaleidoscope of images Huber's need to imitate re-appeared. One surface sign of it appeared when, in hysterical emulation of Raspail and Blanc, he lapsed into a severe faint. He regained consciousness only a half hour later. ${ }^{87} \mathrm{His}$ mind had been exposed to a number of recent and immediate impressions. One was the presence of the extreme radical fringe - in his words, the "anarchist"-minded ones - that had come into being

84 Ibid., p. 3046.

85 Blanc, Révélations historiques, op. cit., II, p. 85.

${ }^{86}$ Stern, Histoire de la Révolution, op. cit., III, pp. 34-35; Weiner, Raspail, op. cit., pp. 225-26.

87 Le Moniteur Universel, 1849, p. 3047. 
before May 15.88 A more immediate image was the inability of anybody, his fellow club leaders included, to quiet the bedlam in the hall. A third particularly disturbing one was the report that the Assembly leaders had sent a call for the National Guard, raising the possibility of bloodshed. ${ }^{89}$ Finally, the incident of Marrast's rejection of him rankled.

After emerging from his faint, Huber moved toward the rostrum. Descriptions of him at this moment convey the sense of a person in an emotional daze. A friend who had observed him previously at times of excitement described him as "overheated, befuddled [s'échauffant, se grisant]". Another perceived him as "very agitated". To the most famous bystander his "clothes [were] in disorder, his look flustered and haggard". 90 In this condition, he pronounced in a stentorian voice his famous words, "In the name of the people, betrayed by their representatives, I declare the Assembly adjourned!" At the same time, he held up a large poster handed to him by another person with almost the same words on it. ${ }^{91}$

Through his act Huber succeeded in reinforcing several of his psychic needs temporarily. The surroundings and the large audience - much more impressive than in his 1835 and 1838 trial scenes - had served to arouse his craving for attention. To this he responded with an exercise in melodrama that riveted everybody's faculties on him. Indeed, his histrionics proved to be so impressive that, after a few more minutes of uproar, the vast majority, deputies included, filed resignedly out of the building. In the sphere of conventional communication, this outcome meant that, in a sense, Huber had resolved the crisis, and without bloodshed. He made exactly this claim at his trial later, and with some justification. ${ }^{92}$ More deeply, much else existed. When, by his unaided act, he dissolved the chamber, he succeeded, in symbolic fashion, in carrying out the coup that the extremists in the Sobrier circle had been merely dreaming about. Further, since the dissolution was bound to be very disturbing to the Mayor, in view of the probable adverse public reaction, he had obtained revenge for the injury to his amour-propre at the time when he was expelled from the building. Finally, it is possible that the particular form that Huber's feat took may have been yet another expression of his penchant to imitate. At the moment of victory in the February Revolution one proclamation after another had been issued "In the name of the French people" to the clamorous

88 Ibid., p. 3045.

89 Ibid., p. 3059.

90 Ibid., p. 3058; Alexis de Tocqueville, Souvenirs (Paris, 1942), p. 123.

91 Le Moniteur Universel, 1849, p. 3059.

92 Ibid., pp. 3047, 3058, 3078. 
public. Even his holding up of the sign had an antecedent, for at the City Hall on the evening of February 24 a large cloth banner hailing the Republic had been raised to inform the riotous crowd without. ${ }^{93}$

When Huber himself exited from the building, the fantasy propensity in him had gained free rein. In recalling his departure, he said that the populace acclaimed him. In Paris, 150,000 people looked to him as their leader. Evidently, as the dissolution itself had shown, he was, in one aspect of his mind, in the grip of the extremists' notion of a new revolutionary government, because he announced to another: "we are in a revolution, [. . . t take sides; [. . . ] we are on the way to the City Hall". Passing a military force that looked as if it might stop him, he declared: "In the name of the provisional government, [...] let me pass." He stopped off in a café and there, in a gesture remindful of his "treaty" between the "French Republic" and Steuble in 1837, he dictated a proclamation naming a new set of officials, but excluding himself. That his people might feel reassured, their self-abnegating leader directed an acquaintance to print up 100,000 copies informing them of what had happened. ${ }^{94}$

Then Huber's world of daydreams came to an abrupt end. Re-appearing in the streets en route to the City Hall, he was recognized and arrested, only to be immediately released due to the confusing circumstances. Meantime, at the City Hall, where, in response to the dissolution surprise, the longchance attempt had been made to create a radical new regime, order was quickly restored. Similarly, the Assembly shortly re-convened. The fury of the reaction, leading to the June Days, had begun. In Huber's case, longtime friends hid him for seven months, after which - as we have seen - he fled to London until late in the Bourges trial. ${ }^{95}$

Common sense would suggest that, after the May 15 fiasco, Huber's opportunities for creating unpleasant political surprises had been exhausted. Yet, two remained. One was the very fact of his return from London, despite certain arrest, trial and conviction. One can imagine the embarrassment of the 1849 government at the thought that the return of this nuisance would make it unavoidable for him to have to be tried. For a few others - such as Delescluze, briefly - the suspicion that he was Marrast's agent seemed unwarranted, since, if he had been, having escaped, surely he would not have returned. It was the strong hysterical component of guilt that pulled him back. Also, the constant need for

93 Stern, Histoire de la Révolution, I, pp. 254-57.

94 Le Moniteur Universel, 1849, pp. 3045, 3047, 3063.

95 Ibid., pp. 3047, 3064; Amann, "A Journée in the Making", pp. 66-68. 
histrionics caused him to sense that if he returned, he might once more be the focal point in a major trial.

Imprisoned following his conviction at Versailles, after only three years Huber authored his final surprise. He, the lifelong radical republican, requested a pardon from Lou is Napoleon. During Louis-Philippe's time he had tried without success to do the same thing. This suggests that there were limits to his self-induced martyrdom. Shortly after the December 1851 coup d'état and the plebiscite he wrote Louis Napoleon appealing for his release. In his letter, the usual elements of masochism - "whatever be my fate" and histrionics - "I accept the will of the people" - appeared. ${ }^{96}$ Further, he strove (as on earlier occasions in different ways, he had with Delessert and Marrast) to prove his worth to the regime by circulating his compliant letter among other political prisoners, soliciting them to join with him in his pardon request. In this he decidedly had no success. ${ }^{97}$ Nevertheless, the government, pleased with its catch, quickly released him, taking care to publish his epistle in the official journal for all to read. ${ }^{98}$

This episode finished Huber as a political figure. At liberty, with the assistance of the authorities, he spent the rest of his days in promotional work connected with the building expansion of the 1850 's. ${ }^{99}$ It was while so employed that he served improbably as Proudhon's partner. Among radicals, liberals and humanitarians, Proudhon alone was gullible enough to have any further relations with him. Proudhon, unlike those who had gone before him, had extreme good fortune in that in his association with Huber, he managed to escape with nothing worse than a minor burn. ${ }^{100}$ As for Huber, before long one of his fantasy tales - this one, a story of his skill as a financial manipulator and of his rich contacts - aroused the suspicions of Bonapartist middle-level officials. This led to his being put under surveillance. ${ }^{101}$ In the 1860 's he published his prison recollections, but they drew attention only as a curiosity. ${ }^{102}$ In 1865 Huber's life of many selves ended rather suddenly when he died of an aneurism. ${ }^{103}$

The damage wrought by Huber's aberrations was remarkable. Laure Grouvelle and Jacob Steuble paid with their lives for their association with

\footnotetext{
96 Ministry of Justice, Requests for Pardons, February 10, 1852, Archives Nationales, $\mathrm{BB}^{21}$.

${ }_{97}$ Sébastien Commissaire, Mémoires et souvenirs (Paris, 1882), II, p. 7.

98 Le Moniteur Universel, 1852, p. 251; Le Moniteur des Communes, February 23, 1852.

99 Grand Dictionnaire universel, IX, p. 426.

100 The Proudhon-Huber partnership is recounted in Darimon, A travers la révolution, op. cit., pp. 303-08.

101 Archives Nationales, BB $^{30}$, Ministry of the Interior, 416, No 1303 P.

102 Huber, Nuits de veille, passim.

103 See note 30.
} 
him. Further, Marrast, Blanqui, Barbès and Raspail suffered severe injury to their political lives due to their connection with him. Most important, the Second Republic received a damaging blow to its moral stature, thanks to Huber's act on May 15, 1848. In Tocqueville's words, referring specifically to Huber, "in democratic revolutions, madmen [...] have played a very considerable political part." 104 Obviously he overstated both the proportions of Huber's maladjustment and the weight of the individual in shaping the course of events. Nevertheless, his perception with regard to Huber seems to fit in with his more general political acumen for which he is famous.

104 Tocqueville, Souvenirs, op. cit., p. 124. 